\title{
Research on China's Interactive Mechanism between Higher Education of Law and Senior High School Education
}

\author{
Zeng Meng ${ }^{1}$
}

\begin{abstract}
${ }^{1}$ School of Law, Huaqiao University, Quanzhou, China
Abstract: The reform of China's college entrance examination requires the transformation of the educational concept from "examination-oriented education" to "professional talent training", which challenges the ability of high school teachers and students to collect and process information about majors and related industries. However, due to the limitation of high school education resources, its subject career guidance cannot break through the information barrier independently, which provides an opportunity for universities to carry out vertical inter-school cooperation and seek multi-dimensional interests under the systematic cultivation of law talents. The interaction mechanism is designed based on the demand characteristics of high school students, vertical cooperation management docking mode, and information exchange community. On this basis, it includes the annual practice of legal practice experience, sharing of graduate school level scientific research projects, moot court, legal clinic, one-way annual lecture, alumni return visit, undergraduate classroom experience, and other forms of activities. Although the development of interactive mechanism needs decentralization and incentive, only by being supervised, fully protecting students' rights and interests, and respecting education fairness can it exist in the long run
\end{abstract}

Keywords: Higher Education of Law, Senior High School Education, Vertical Inter-school Cooperation, Reform of College Entrance Examination, Subject Career Guidance

\section{Introduction:}

Challenges and opportunities of breaking through information barriers under the background of college entrance examination reform

In 2014, the Opinions of the State Council on Deepening the Reform of Examination and Enrollment System began a new round of reform of the college entrance examination. The new formations, for example, high school students independently select test subjects (including " $3+3 "$ and " $3+1+2 "$ models), university application is comprehensively filled in according to majors and schools (including "academic majors group " and "major + school" models), etc. reflect the concept transformation from "examination-oriented education " to "professional talent training". In 2021, with the third batch of pilot provinces for college entrance examination reform ushering in the first new college entrance examination candidates, the impact of this round of college entrance examination reform will further expand, which also poses challenges to high school education. Firstly, high school students need to plan their undergraduate majors or career, so that they can determine the subjects of college entrance examination according to the requirements of corresponding majors. Secondly, high school students must at least understand the ranking of colleges and universities offering the majors, which mainly refers to the "Discipline Evaluation Ranking of the Ministry of education", to reasonably arrange the application order of majors. This improves the bottom-line requirements of information collection and processing compared with most high school students determine the order of majors only according to the hearsay of public opinion of universities before the reform. Finally, most high school teachers who are in the field of basic education and not involved in academics need to overcome the limitations of experience to provide high school students with scientific subject career guidance.

The essence of the above challenges faced by high school teachers and students is the information barrier between higher education and basic education. The positive interaction between higher education of law and high school education will not only help high school teachers and students to break through the information barrier, prevent the reform from becoming the tragedy of "I have sown Dragon's teeth and reaped only fleas" ${ }^{\text {[1] }}$, but also generate multi-dimensional benefits on the compliance track of the National Medium and Long-term Education Reform and Development Plan Outline (2010-2020). First, in terms of higher education of law, it is conducive to combining scientific research with teaching and practice, enhancing the social service capabilities of law colleges and universities, comprehensively giving play to the role of professors and postgraduates in voluntary activities and public welfare undertakings, and combining with the independent enrollment system to absorb talents, to form distinctive school-running characteristics and autonomy. Second, in terms of the legal talent training system, it is conducive to combining the reform pilots of top-notch innovative talent training, leading high school students to explore legal professions in preliminary practice, prompting them to rationally examine their enthusiasm to law, and inspiring potential legal talents to set up lofty ideals to promote legislation and judicial justice, and gradually familiarizing them with legal thinking mode in a subtle way, to realize the systematic cultivation of legal

This article is published under the terms of the Creative Commons Attribution License 4.0 Author(s) retain the copyright of this article. Publication rights with Alkhaer Publications. Published at: http://www.ijsciences.com/pub/issue/2021-08/

DOI: 10.18483/ijSci.2496; Online ISSN: 2305-3925; Print ISSN: 2410-4477 
talents in the effective interactive mechanism between universities and high schools. Third, in terms of governing education according to the law, it is conducive to the development of law popularization education at the two levels of student education and high school teacher education and enables law researchers to have a sufficient empirical basis to uncover the shortcomings and omissions of current education laws and regulations, and then put forward the legislative improvement scheme with strategic position, pertinence and operability.

\section{The necessity of vertical interaction: high school education cannot cope with Information barriers independently}

Although the imported subject career guidance is a way for high schools to break through information barriers, its implementation in China is not good. The following two sets of empirical survey data are used to illustrate it from different perspectives. The first set of empirical survey data ${ }^{[2]}$ takes 67 districts (counties) in Zhejiang Province as a sample, which are distributed in urban, township, and rural areas, with a total of 201 junior high schools, senior high schools, and vocational high schools. (Each type of school accounts for one-third of the number of schools) It macroscopically shows the problems existing in the subject career guidance. First, the introduction of subject career guidance is relatively late. Only $49.1 \%$ of schools had carried out subject career guidance before 2014. More than half of the schools passively and gradually implemented subject career guidance work after the new round of college entrance examination reform in 2014. This makes the theory and experience of subject career guidance lack accumulation in the historical background that has not been valued for a long time in China, and relevant teachers can only "cross the river by feeling the stones" at the cost of teaching effectiveness in constant trial and error. Second, the effect of subject career guidance work is minimal. According to the results of 25,509 student questionnaires, $41.3 \%$ of the students rarely participated in the activities related to subject career guidance organized by the school, and $26.2 \%$ of the students had never participated in the activities related to subject career guidance organized by the school. Among the students who participated in the activities related to subject career guidance, only $29.8 \%$ of the students are "very satisfied" with the effect, while $15.1 \%$ of the students are "dissatisfied" with the effect. Third, the corresponding professional ability of the teaching staff in charge of subject career guidance is generally low. In $58.2 \%$ of the schools, full-time or part-time psychological teachers are in charge of subject career guidance, while in $20.2 \%$ of the schools, headteachers are in charge of subject career guidance. That is to say, for most persons in charge, subject career guidance is neither the main content of their education experience nor the main content of their current work. Therefore, they are not qualified for this job no matter from the perspective of theoretical knowledge or practical skills. Among them, $30.4 \%$ of teachers are even directly responsible for subject career guidance without any pre-job training. In addition, in the 1085 teacher questionnaires, $56.6 \%$ of teachers believe that the biggest obstacle to smoothly carrying out subject career guidance is the weakness of professionals and teachers. Other obstacles include that career guidance is not included in the curriculum system, lack of class hours and funding support, lack of supporting system and policy support, etc.

Any application of educational resources, teaching methods, teaching content, etc. are attached to the active subject ${ }^{[3]}$. Teachers are always at the core of influencing the effectiveness of teaching. Even in the creative classroom with students as the main body, it still depends on the degree of freedom and heuristic guidance given to students by teachers' personal subjective judgment. The same is true of the importance of teachers' personal ability to subject career guidance. Based on the first group of empirical survey data, the second group of data ${ }^{[4]}$ further analyzes the current situation of high school teachers' ability of subject career guidance from the micro perspective. Combined with the Likert 5-point scale method, it divides the corresponding professional skills that high school teachers should master into five first-level indexes:" consciousness and attitude of subject career guidance", " ability of subject career information collection and processing", "subject teaching ability integrated with career guidance"," consultation ability of subject career", " counseling ability of study and career Plan ", then they are subdivided into 13 corresponding second-level indexes. A total of 234 valid questionnaires were collected from teachers from 15 high schools in Shanghai who participated in the summer seminar of East China Normal University in 2019. The statistical results show that the average score of " consciousness and attitude of subject career guidance" is the highest, reaching 3.99, and the two first-level indexes with the lowest average scores are " consultation ability of subject career" (3.18) and " ability of subject career information collection and processing" (3.53). While the two abilities with the lowest average score are exactly the core of subject career guidance ability. This shows that although high school teachers have recognized the importance of subject career guidance, they have not yet acquired the corresponding professional skills. Although the limited ability of high school teachers' subject career guidance makes high school teachers not accountable under the background of education stages and established teacher education mechanism, from an objective point of view, this " limitation" is not only the main factor restricting the quality of subject career education but also the crux of high school education's failure to break through the information barrier independently. As far as the law-related industries are concerned, the huge major barriers and the relative sensitivity of the information in related industries, such as courts, procuratorates, law firms, notary offices, etc. have further increased the difficulty for high school teachers to carry out subject career guidance in law. 
Regarding the choice of solutions to break through information barriers, whether it is to reform the content and assessment standards of teacher education, or to formulate a career guidance mechanism under the jurisdiction of the ministry and province, it is a long cycle and high cost. While relying on the existing resources of higher education of law and promoting its diversified interaction with high school education, we can achieve the above-mentioned multi-dimensional benefits at a low cost and immediately when the reform of college entrance examination has been carried out in full swing.

\section{Native interaction mechanism: operational construction based on the references of internal and external experience.}

3.1 Three bottom designs of the multiple interaction mechanism

3.1.1 Different needs of high school students in different grades for the interactive mechanism

Most high schools require students to choose their examination subjects from the end of grade one to the beginning of the autumn semester of grade two. A few students will change their examination subjects after the beginning of grade two on the ground of "not adapting to the learning of the originally selected subjects". At the same time, the students of grade two and grade three are faced with greater academic pressure than the students of grade one. Therefore, the first-year students should be the most extensive and in-depth group to participate in the interactive mechanism, and the interactive mechanism integrated with the subject career guidance should be included in the curriculum system of the first-year students and have the guarantee of independent class hours. The second-year students who are interested in the selected subjects and meet the registration requirements of law major can retain the channels of obtaining law-related information, consulting and communicating in the interactive mechanism, and participate in some activities in their after-school time. After-school time refers to weekends, statutory holidays, winter and summer vacations, while the time after school on weekdays is not included. Second-year or third-year students who intend to change the originally selected subjects will participate in the interactive mechanism according to the relevant regulations of the first-year students before the moment of determining the changed subject. After the change of subjects is determined, the third-year students will no longer participate in the interactive mechanism.

\subsubsection{Management docking model between high} schools and law colleges

The specific person in charge of the management docking work in high school is the teacher of subject career guidance. According to the above mechanism design, since the subject career guidance curriculum has been incorporated into the curriculum system of high school students, it is not difficult for teachers of this course to collect relevant information and connect with the staff of institutions of higher education. In consideration of a small number of second-year students who need to participate in the relevant activities of interactive mechanism, the teacher only needs to check the authenticity of the students' participation information with the staff of colleges. In consideration of individual students who plan to change their choice of subjects after the start of the second grade and need to participate in the interactive mechanism more deeply, they are directly managed according to the curriculum rules of the first-year students.

The personnel composition of the interactive mechanism in law colleges is more complicated than that of high schools. First, colleges select the hosts from teachers who have the title of professor and associate professor of law referring to the management mode of scientific research project, and authorize them to carry out the specific content of the activities in that year and provide fund support from "first-class discipline construction" or similar projects. Relevant administrative departments assist according to the authorization content obtained by the hosts and supervise the behaviors violating professional ethics. Second, compared with undergraduates and teachers in administrative posts, postgraduates have advantages in national and global academic conferences, high-quality discipline competitions, scientific research projects, academic achievements, practical experience in law-related industries, etc. Their learning and scientific research content have largely got rid of the dependence on the classroom, and their participation in the interaction mechanism is also conducive to researches in the interdisciplinary fields of law and pedagogy, legal professional system, and so on. Therefore, graduate students should be the main members of the specific operation in interaction mechanism, and the Handover of management work between graduate students and high school teachers can give consideration to both the efficiency and cost of human resources. In terms of the corresponding incentive mechanism, the above-mentioned work of graduate students can be included in the work-study positions of colleges and then subsidized, or it can be counted as participating in school-level academic projects and then bonus points for scholarship evaluation.

\subsubsection{Information communication channel and community}

Massachusetts Institute of Technology has extensive experience in the construction of learning and communication platforms. Its "u. lab" learning platform can provide users with an online learning platform for online reading, online training, and watching audiovisual materials, as well as an offline learning platform for common communication and practice, and then form a community-based contact among users. Based on "u. lab", the Scottish government has also established a mutual aid community for the marginalized groups, which can be used as a channel of assistance and increase their sense of social integration. 
Eva Pomeroy, a teacher at Concordia University, spoke highly of "u. lab" after a survey, believing that it can promote the education of connecting people, bridging differences, and abandoning campus exclusion as David Orr said ${ }^{[5]}$.

Inspired by the construction experience of " $u$. lab", the construction of information communication channel and community of interactive mechanism can be divided into three levels. First, the exertion of management effectiveness. Teachers of high school subject career guidance course will sort out the list of students participating in the interaction mechanism and share it with the graduate students in charge of the corresponding work. With the help of Tencent Conference, e-mail, WeChat group, QQ group, and other platforms, the graduate students will establish communication channels with instant messaging, information disclosure, file transmission, online conference, and other functions. High school teachers in charge of subject career guidance courses, students participating in the interactive mechanism, graduate students in charge of the corresponding work, and university teachers who hosted the interactive mechanism at that time are all members of the communication community. Second, the students in the second-year or third-year who have finished the subject career guidance course can still stay in the same-school communication community to obtain the latest developments of the interaction mechanism and relevant information of law. Third, after the college admission notice is issued, the teachers and graduate students will jointly count the list of students who are admitted into schools of law, and establish a communication community for all students who have studied law since the implementation of the interactive mechanism, regardless of school, region and grade, so that they can share academic or practical resources for a long time. Finally, the students who have not studied law are supposed to leave the communication community.

\subsection{Activities in the interactive mechanism 3.2.1 Annual internship of legal practice}

Morgan Polikoff and David M. Quinn, scholars of the University of Southern California, elaborated on the problem of students wasting summer study time in a survey report called Summer Learning Loss: What Is It, and What Can We Do about It? Aiming at the same problem, Kylie Chandler Alcott, dean and professor of the writing school of Syracuse University, integrates the resources in the school and provides a three-week free writing course for local junior high school graduates in summer to help them transition to senior high school ${ }^{[6]}$. In terms of interactive mechanism, making good use of the long vacation of first-grade students not only helps them to reduce the waste of summer study time but also transmit more systematic law-related professional information to them.

In China, many law colleges organize undergraduates to practice in courts, procuratorates, and law firms every year. Taking Southwest University of Political Science and Law as an example, which is rated $\mathrm{A}$ in the fourth law discipline assessment by the Ministry of education. It arranges unified internships for second-year students from early July to late September every year. The school and the internship unit have signed internship agreements, and there are usually other cooperative relations between the two units or their employees, for example, the judges of the court come to the school for training from time to time, the court entrusts the school to undertake judicial research projects, and the school teachers are employed as court consulting experts. Based on the existence of the above cooperative relation, the probability of students suffering from workplace bullying or right infringement in internship units is greatly reduced. In addition, each practice area is equipped with instructors to help students solve their difficulties and assess their practice situation, so as to pay more attention to the physical and mental health of students.

The safe practice environment and sound practice system provide the feasibility for high school students to participate in the annual practice of law colleges. High school students can take this opportunity to observe the real working state of law industries. Because the annual internship is usually carried out in the summer, and second-year students should spend more time on college entrance examination subjects in the summer, this activity is only for first-year students. They should register with the teachers of the subject career guidance before the end of the spring semester, and then the teachers should hand over the list of students to law colleges. In terms of internship location, because law colleges have many internships in their provinces and cities, and there are a large number of alumni in various fields of law, they can usually provide high school students who participate in this interactive mechanism with internship conditions near their residence. In terms of internship time and tasks, high school students only need to carry out experiential internships within the purpose limit of understanding the real situation of the industry, and they do not need to master the practical skills of law. Therefore, they should speed up the post flow speed among different departments of the same unit and among different units. For example, if a student is interning in a court, he will only intern in the case filing chamber for three days, then transfer to the trial court for three days, and then transfer to the executive board for three days, and so on. In order to reduce the risk of work errors as much as possible, and take into account the purpose of experiential practice, the content of high school students' practice is to assist undergraduates to deal with their work.

\subsubsection{School-level scientific research projects of graduate}

After selection, the graduate's academic project is not only of high quality but also has relatively sufficient fund support. High school students can have a preliminary understanding of differences in legislative 
theory, the judicial treatment of controversial cases, and the dependence on technological rationality of the concept of legal justice from a higher perspective by properly participating in the school-level scientific research projects of graduates, including attending the meetings with the research group, conducting and processing literature collection, and empirical investigation. So as to imperceptibly cultivate their legal thinking models, feel the charm of pursuing legal justice in disputes, and attract high school students to take law as their major. Legal research projects often involve information in legislative, judicial, and academic fields at the same time. For example, the school-level project of Southwest University of Political Science and Law, "the construction of substantive law and procedural law for procuratorates to exercise environmental public interest litigation rights" (Project No. 2015-bzx-031) studies the legal ways of procuratorates, law courts, and NGOs to protect the ecological environment. It is helpful for high school students to understand the situation of various legal professions in specific fields. In addition, scientific research projects usually conclude with the publication of works or papers. High school students who observe graduate students' writing or undertake a small number of writing tasks can improve their Chinese writing ability

\subsection{3 moot court}

Under the guidance of graduate students, high school students carry out moot court activities on hot social cases. The reason why the selected cases must be hot is that although the high school students who participate in the interactive mechanism have a certain enthusiasm for the law, they are still in a wait-and-see state whether they will apply for the law major in the future. Therefore, the selection of hot cases can stimulate their speculative enthusiasm generated by the simple concept of justice, so as to make them more actively integrate into the court trial. High school students play the roles of the plaintiff and the defendant to simulate the thinking mode and work content of lawyers and prosecutors. Some graduate students provide the information needed by the trial, such as the information about indictment, defense, evidence materials, and play the roles of judge, presiding judge, clerk, witness, etc. to control the trial situation. The other part of graduate students will guide the plaintiff and defendant. As long as the difficulty of the provided case materials is mastered, a moot court formed by adding a small amount of legal knowledge on the basis of students' original debating ability will not completely deviate from the cognitive level of high school students.

\subsubsection{Legal Clinic}

The law clinics in law colleges and universities are mainly composed of undergraduate students. A small number of graduate students participate in the organization and guidance, and professors and associate professors are the instructors of activities. There are two working modes of the legal clinic. The first is to set up a legal clinic office in the school to passively provide some legal services to people inside and outside the school, including providing legal advice, drafting, modifying and reviewing contracts, mediation, etc. The second is to take the initiative to set up temporary legal aid points in public places outside the school, such as places near the court, square, residential areas, etc. The first mode usually cannot attract enough people outside the school to seek legal aid. The students in the legal clinic office are basically idle, so high school students do not need to participate in the first mode of legal clinic work. The second mode places free legal services "visible" in crowded places, so more people will come to seek legal aid. Through participating in the second mode, high school students can not only feel the normality, diversity, and complexity of social disputes, but also realize that the core of the legal practice is to resolve disputes, and they can also realize that law is a discipline that can greatly enrich people's social experience.

\subsubsection{One dimensional Annual Lecture}

The smooth development of many activities in the interactive mechanism not only requires the effective work docking between senior high school teachers and university teachers and graduate students but also requires the first-year high school students to have a preliminary understanding of the law discipline, overviews of Law Universities and the operation mode of the interactive mechanism before joining the interactive mechanism. This requires that college teachers and graduate students should introduce relevant information to first-year high students before they formally join the interactive mechanism. On the other hand, according to the above mechanism design, the subject career guidance curriculum of first-year students has independent class hours, so college teachers and graduate students can give a topic lecture for all first-year high school students once a year.

\subsubsection{Alumni return visit}

Based on the construction of the communication community, students who graduated from the same high school participated in the interactive mechanism, and were admitted to the law school with A-level or above of the Ministry of Education can be invited to the subject career guidance class or class meeting to exchange their understanding of the interactive mechanism, school selection experience, and the general situation of law subject of their schools. The teachers of high school subject career guidance course send out the invitation separately according to the curriculum arrangement, and the invitees and high school teachers work together directly. Although the host and graduate students do not intervene in this matter, the return visit can only be carried out after the annual lecture is completed, because the authoritative information about the interaction mechanism, various law schools, and law disciplines introduced to the first-year high school students in the annual lecture can, to a certain extent, correct some deviation of information transmitted by students who have just entered the undergraduate stage of law major. At the 
same time, the risk tips given to the first-year high school students in the annual lecture, for example, one should not blindly worship the teachers and students of famous law schools, can reduce the possibility of high school students suffering from infringement when they participate in the interactive mechanism.

\subsubsection{Experience of law course in undergraduates' classroom}

Rhodes University has established a close vertical school-level cooperation with Gadra Secondary School. One of the contents of the cooperation is that students of Gadra Secondary School can study some courses of business school, science school and Humanities School of Rhodes University while studying high school courses ${ }^{[7]}$. It is slightly different from the mechanism of Rhodes University. In this interactive mechanism, the first-year high school students are not suitable to experience the law class of graduates, because whether the university teachers take law theory as the main teaching content in the graduate class, or take a case study, paper or book introduction as the main teaching content, their premise is that the students have the basic knowledge system of law. While the law class of undergraduates is different. First, teachers in undergraduate classes usually pay more attention to guiding students to establish a connection between life facts and law, and spend a lot of time explaining to students the basic jurisprudence thinking behind the legal theoretical disputes. Second, the goal of the undergraduate course is not to study the sub-discipline of law, but to make the students have systematic cognition of the knowledge of the law as far as possible, that is, every course is based on the assumption that the students learn the relevant department law for the first time, which provides the possibility for high school students to get a sense of integration and harvest in the course.

\section{Conclusion: the sustainable development of interactive mechanism under supervision}

In addition to the lack of professional knowledge of various industries, high school students also lack experience in other aspects, such as property fraud, emotional deception, false publicity of teaching and academic. Although the interactive mechanism gives high school students rich experience and accelerates their growth on the career path, it also objectively increases their personal and property risks. Therefore, it is necessary for colleges and high schools to pay daily attention to the interpersonal and working conditions of high school students in the activities, and require colleges to abide by the Opinions of the Ministry of Education on Further Improving and Standardizing the Pilot Work of Independent Enrollment in Colleges and Universities (2014) and not abuse the right of independent enrollment. Only an interactive mechanism that can not only protect the rights and interests of high school students, respect education fairness, but also ensure the quality of work can develop healthily and sustainably.

\section{Conflict of Interest}

The author declares no conflict of interest.

\section{References}

1. Marx, Engels. (1995) Selected Works of Marx and Engels (Volume 4). Translated by the Translation Bureau of the Central Committee of the Communist Party of China. Beijing: People's Publishing House: 476

2. Ruan Lingling. (2018) Investigation on the Current Situation of Subject Career Guidance in High Schools in Zhejiang Province. Journal of Shanghai Educational Research, 8, 44-48.

3. Xiong Chuanwu. (1998) On the Modernization of Educational Subject in the View of Postmodernism. Journal of East China Normal University (Educational Sciences): 8-16.

4. Zheng Yajun. (2020) A study of the Status Quo and Influence Mechanisms of High School Teachers' Subject Career Guidance Competency. East China Normal University: 51-52.

5. Eva Pomeroy. (2018) Why Universities Need Homerooms. The Conversation.

https://theconversation.com/why-universities-need-homerooms106299.

6. Kelly Chandler. (2019) What Advice Articles Miss about Summer Loss. The Conversation.

https://theconversation.com/what-advice-articles-miss-about-su mmer-loss-118430.

7. Di Wilmot. (2019) Fixing South Africa's Public Schools Lessons from a Small-town University. The Conversation. https://theconversation.com/fixing-south-Africa's-public-school s-lessons-from-a-small-town-university-113206. 